\title{
Formation of a value attitude to health among younger school children in an innovative educational environment
}

\section{Formação de uma atitude de valor para a saúde entre os alunos mais jovens em um ambiente educacional inovador}

\section{Formación de una actitud de valor hacia la salud entre los escolares más pequeños en un entorno educativo innovador}

\author{
Victor Konstantinovich Vittenbek ${ }^{1}$ iD , Maryam Rashidovna Koreneva $^{1}$ (D), \\ Konstantin Pavlovich Yadrov ${ }^{1}$ (i), Galina Pavlovna Ivanova ${ }^{1}$ (iD, \\ Anna Sergeevna Moskvina ${ }^{1}$ iD
}

\begin{abstract}
${ }^{1}$ Moscow Region State University, Moscow, Russia.
Corresponding author:

Victor Konstantinovich Vittenbek

Email:v.vittenbek@mail.ru

How to cite: Vittenbek, V. K., Kpreneva, M. R., Yadrov, K. P., Ivanova, G. P., \& Moskvina, A. S. (2021). Formation of a value attitude to health among younger school children in an innovative educational environment. Revista Tempos $e$ Espaços em Educação, 14(33), e16753. http://dx.doi.org/10.20952/revtee.v14i33.16753
\end{abstract}

\begin{abstract}
The purpose of the research: to study the substantive foundations of the organization of health education and health savings in younger schoolchildren; to develop a "Health saving space of a child in an innovative educational environment" model; to evaluate the effectiveness of the use of an educational project. The study involved 44 children from the 2 nd grade (Gymnasium No. 1 of the city of Krasnozmensk, Moscow region); 44 parents; scientific and pedagogical staff. Based on the study of scientific literature, theoretical analysis and systematization of domestic experience on the problem of value attitude to the health of younger schoolchildren have been carried out. The following methods were used in the course of the study: the observation method; the author's questionnaire (the study of the attitude of younger schoolchildren to their health); "The methodology of the study of value orientations" (M. Rokich). The conducted empirical study confirmed the hypothesis about the need to form a value-based attitude to health in children. The research is a necessary direction in the development of preventive pedagogy and psychology on health education and health saving of children. The materials of the article can be used by teachers, psychologists, teachers, students.

Keywords: Educational work. Health. Health-saving pedagogy. Innovative educational environment. Primary school student. Value orientations.
\end{abstract}

RESUMO 
O objetivo da pesquisa: estudar os fundamentos substantivos da organização da educação em saúde e da economia em saúde em alunos mais jovens; desenvolver um modelo "Espaço de economia da saúde da criança em um ambiente educacional inovador"; avaliar a eficácia da utilização de um projeto educacional. 0 estudo envolveu 44 crianças da 2a série (Ginásio no 1 da cidade de Krasnozmensk, região de Moscou); 44 pais; pessoal científico e pedagógico. Com base no estudo da literatura científica, procedeu-se à análise teórica e sistematização da vivência doméstica sobre a problemática da atitude de valor para a saúde dos escolares mais jovens. Os seguintes métodos foram usados no decorrer do estudo: o método de observação; o questionário do autor (estudo da atitude dos escolares mais jovens em relação à saúde); "A metodologia do estudo das orientações de valor" (M. Rokich). O estudo empírico realizado confirmou a hipótese sobre a necessidade de se formar uma atitude baseada em valores para a saúde das crianças. A pesquisa é uma direção necessária no desenvolvimento da pedagogia preventiva e da psicologia na educação para a saúde e salvando a saúde das crianças. Os materiais do artigo podem ser utilizados por professores, psicólogos, professores, alunos.

Palavras-chave: Trabalho educacional. Saúde. Pedagogia salvadora da saúde. Ambiente educacional inovador. Aluno da escola primária. Orientações de valor.

\section{RESUMEN}

El propósito de la investigación: estudiar los fundamentos sustantivos de la organización de la educación para la salud y el ahorro para la salud en los escolares más pequeños; desarrollar un modelo de "Espacio de ahorro de salud de un niño en un entorno educativo innovador"; evaluar la efectividad del uso de un proyecto educativo. El estudio involucró a 44 niños de segundo grado (Gymnasium No. 1 de la ciudad de Krasnozmensk, región de Moscú); 44 padres; personal científico y pedagógico. A partir del estudio de la literatura científica se ha realizado un análisis teórico y una sistematización de la experiencia doméstica sobre el problema de la actitud valorativa ante la salud de los escolares más jóvenes. En el curso del estudio se utilizaron los siguientes métodos: el método de observación; el cuestionario del autor (el estudio de la actitud de los escolares más jóvenes hacia su salud); "La metodología del estudio de las orientaciones valorativas" (M. Rokich). El estudio empírico realizado confirmó la hipótesis sobre la necesidad de formar una actitud basada en valores hacia la salud en los niños. La investigación es una dirección necesaria en el desarrollo de la pedagogía preventiva y la psicología en la educación para la salud y el ahorro de la salud de los niños. Los materiales del artículo pueden ser utilizados por profesores, psicólogos, profesores, estudiantes.

Palabras clave: Trabajo educativo. Salud. Pedagogía salvadora de la salud. Entorno educativo innovador. Estudiante de primaria. Orientaciones de valor.

\section{INTRODUCTION}

The new reality and necessity of the modern education system in Russia is the teaching of primary school children to lead a healthy lifestyle in an innovative educational environment. The organization, dissemination, and daily implementation of teaching students the fundamental principles of preserving health, strengthening it, and leading children to a healthy lifestyle, did not always take place in full and "smoothly" both in the family and in educational institutions.

Currently, Russian education is characterized by traditional forms of education and the upbringing of children. The existing training of students and the development of certain skills, knowledge, and abilities for preserving and strengthening their health, leading a healthy lifestyle by them is still "minimized" and "requires" an urgent comprehensive solution from both the family in which the child lives and is brought up and from the educational organization (Yadrov, 2016a; 2016b; Bryantseva et al., 2019). 
A person's vision has always acted and acts as an absolute value throughout his/her life path. Currently, there is a persistent tendency to reduce the level of health indicators of the Russian population. According to experts of the Research Institute of Hygiene and Health Protection of Children and Adolescents, the FSAI "National Scientific and Practical Center for Children's Health", the Ministry of Health of the Russian Federation for 2017, there are practically no completely healthy children among students of secondary schools (Decree of the President of the Russian Federation No. 761, 2012). As of September 2018, the number of absolutely healthy school-age children was about $12 \%$ of the total number, and every second student was exposed to some kind of chronic disease. In addition, over the past 10 years, doctors have noted a steady increase in the frequency of functional health disorders among the younger generation and the fixation of chronic diseases in them (Ankov, 2017). Therefore, it is not necessary to form a perception of peculiar health, starting from a very early age, and even more so - in a lockdown situation. The group of primary school age was and remains the most acceptable for this process since this age period is the most sensitive for the implementation of pedagogic and recreational, and educational influences. In addition, with the beginning of educational activities, the conditions of life, and its rhythm, the usual list of responsibilities change dramatically for children of primary school age; at the same time, younger schoolchildren have acquired dominant needs - obtaining new knowledge (Vittenbek \& Maksimenko, 2019; Decree of the President of the Russian Federation No. 761, 2012). One of the important and necessary components of knowledge for a younger student is the study of the phenomenon of "health" and the need to save it in an innovative educational environment. This was the starting point for the study.

\section{METHODS}

The purpose of this study was to identify the level of formation of a value attitude to health in an innovative educational environment in younger schoolchildren; to study the content foundations of the organization of health education and health savings in the space of educational and extracurricular activities; to develop and test the "Health saving space of a child in an innovative educational environment" model using the educational project - "Formation of components of a value attitude to health in younger schoolchildren using information technologies".

The following methods were used in the course of the study: the observation method; the author's questionnaire (the study of the attitude of younger schoolchildren to their health); "The methodology of the study of value orientations" (M. Rokich).

The analysis of the relevance of the research topic allowed identifying two contradictions:

- trends in education and Federal Standards of Education (FSES, art. 2. p. 10, 12, art. 3, p. 16) are aimed at "forming an attitude to a safe, healthy lifestyle"; "mastering the basics of environmental literacy, elementary rules of moral behavior in the world of nature and people, norms of health-saving behavior in the natural and social environment", "forming an ecological culture, a healthy and safe lifestyle". Nevertheless, even if there are events of different levels related to the promotion of a healthy lifestyle and the implementation of the ideas of this direction, there are insufficient opportunities for academic disciplines to promote this knowledge to children of primary school age in a single educational space;

- between a fairly complete theoretical study of this issue and the widespread practice of forming value relations to health among younger schoolchildren and the lack of a training project adapted to the conditions and capabilities of a specific educational organization within the framework of its implementation among students.

We put forward a research hypothesis in the course of studying this problem: the formation of a value attitude to health in younger schoolchildren will be effective if: 
- a team of specialists (a teacher, a psychologist, parents) will be able to form a certain value attitude to their health during the educational process and the organization of leisure activities among children of primary school age;

- educational and leisure work among younger schoolchildren will be carried out with the obligatory "inclusion" of cognitive, emotional, activity, and value components;

- a special educational project will be used in the process of forming a value attitude to health among younger schoolchildren.

The following tasks were solved in the research:

1. Analytical and pedagogical analysis of health-saving programs and their component content.

The first task was solved by theoretical study and analysis of existing health education programs for preschoolers and schoolchildren (Table 1).

Table 1. Analytical and pedagogical analysis of health-saving programs for preschoolers and schoolchildren

\begin{tabular}{|c|c|c|}
\hline $\begin{array}{l}\text { The author of the } \\
\text { Program }\end{array}$ & Program name & Program features \\
\hline 1 & 2 & 3 \\
\hline $\begin{array}{l}\text { T. S. } \quad \text { Kazakovtsev } \\
\text { (2018) }\end{array}$ & $\begin{array}{l}\text { Program on the } \\
\text { formation of } \\
\text { healthy lifestyle } \\
\text { skills for children } \\
\text { aged } 7-10 \text { years } \\
\text { "Health Secrets" }\end{array}$ & $\begin{array}{l}\text { Purpose: To promote the formation of children's } \\
\text { motivation for a healthy lifestyle and their } \\
\text { responsible behavior to preserve and strengthen } \\
\text { their health. Forms of training: sports events, film } \\
\text { demonstrations, fun starts, contests, } \\
\text { questionnaires, games, thematic quizzes, travel, } \\
\text { conversations, wellness minutes, meeting with a } \\
\text { pediatrician, watching videos with subsequent } \\
\text { discussion, exhibitions of drawings, actions to } \\
\text { protect a person from the influence of bad habits }\end{array}$ \\
\hline $\begin{array}{ll}\text { V.P. } & \text { Shcherbakov } \\
(2018) & \end{array}$ & $\begin{array}{l}\text { "Physical } \\
\text { education from } 3 \\
\text { to } 17 \text { years" } \\
\text { partial program }\end{array}$ & $\begin{array}{l}\text { It provides for continuous physical culture and } \\
\text { health education for children from } 3 \text { to } 17 \text { years } \\
\text { old. The content is selected in such a way that } \\
\text { allows developing all types of motor activity. }\end{array}$ \\
\hline L. Dmitrieva (2016) & $\begin{array}{l}\text { "Health from } \\
\text { childhood" partial } \\
\text { program }\end{array}$ & $\begin{array}{l}\text { It is aimed at the formation of valeological and } \\
\text { physical culture in preschool children, I.e. culture } \\
\text { of health, healthy lifestyle, movements }\end{array}$ \\
\hline Voitenkova & $\begin{array}{l}\text { "Formation of a } \\
\text { healthy lifestyle } \\
\text { among children } \\
\text { from orphanages } \\
\text { aged } 7 \text { to } 14 \text { years } \\
\text { old" program }\end{array}$ & $\begin{array}{l}\text { Purpose: The formation of children's social skills } \\
\text { that ensure physical and mental health, intense } \\
\text { activity, and longevity. }\end{array}$ \\
\hline
\end{tabular}




\begin{tabular}{|l|l|l|}
\hline N.I. Alonkina (2014) & $\begin{array}{l}\text { "School of Health" } \\
\text { program }\end{array}$ & $\begin{array}{l}\text { Objectives: development of organizational, } \\
\text { software, and logistical support for additional } \\
\text { education of students in the aspects of health } \\
\text { savings, their recreation, leisure; formation of } \\
\text { students' understanding of the importance of } \\
\text { preserving, strengthening health and healthy } \\
\text { lifestyle skills; formation of an idea of the basics of } \\
\text { ecological culture on the example of } \\
\text { environmentally consistent behavior in everyday } \\
\text { life and nature, safe for humans and the } \\
\text { environment. }\end{array}$ \\
\hline $\begin{array}{l}\text { S.R. Dolgopolova } \\
(2012)\end{array}$ & "Schoolchildren's \\
Health" program & $\begin{array}{l}\text { The main task: to become a health school, where, } \\
\text { along with teaching children, significant attention } \\
\text { is paid to the maximum realization of the physical, } \\
\text { psychological, and social potential of both children } \\
\text { and adults, the acquisition of knowledge, and the } \\
\text { development of skills necessary for making } \\
\text { decisions related to their health, as well as for } \\
\text { preserving and improving a healthy environment. }\end{array}$ \\
\hline
\end{tabular}

As can be seen from the table presented, all health-saving programs affect the attention of parents and children from the position of their familiarization with the technologies of health saving (through physical, psychological, and social perfection) (Kamakina, 2017), but do not solve the main task - understanding the need for a value attitude to their health, its preservation, and strengthening.

The second task was solved by developing the "Health-saving space of a child in an innovative educational environment" program and implementing it by using the educational project in the conditions of "remote" work with children and their parents. The solution to this problem was "built" based on a document - the Federal State Educational Standard, which suggests considering the health and education of children through the prism of experimental and research activities. During the research, we "relied" on these positions.

Currently, the work of modern educational organizations on the formation of children's ideas about a healthy lifestyle and value attitude to it is based on the use of health-saving technologies (Lukashenko \& Lukashenko, 2017; Tsyrenova, 2015). These technologies are inextricably linked with the health-saving environment, which is considered by researchers through the prism of subjectspatial or material-technological aspects (Zimina \& Mukhina, 2016). Previous studies have found that when solving problems of this level, the potential of the child should be concentrated on the physical education of children (Pleshchev, 2018). However, as our research has shown, it is the forms of extracurricular work - educational and physical culture and leisure activities that make up a single value-oriented space - that can become the most effective in solving problems of this level. Therewith, the effectiveness of the formation of a value attitude to health directly depends on the comprehensive development of the student's personality and the activity of his/her health-saving position (Kaznacheev, 2012; Kalanchina \& Apenysheva, 2019). It is impossible to exclude the importance and role of the child's family in these processes, in which health-oriented family traditions and the personal example of parents have had and have a strong impact on the development of his/her personality. Considering the importance and role of parents in the life of a child, the peculiarities of health-improving, educational work in the conditions of innovative learning, we developed the "Health-saving space of a child in an innovative educational environment" model in the course of the study in lockdown conditions (Figure 1). 


\section{Health is a child's}

saving space

\section{Educational and cognitive activities of children and parents}

3. Motor and play activity of children

Figure 1. "Health-saving space of a child in an innovative educational environment" model.

For the process of forming a value attitude to health among younger schoolchildren to be effective in lockdown, we used certain pedagogical conditions:

- upbringing a value attitude to health in younger schoolchildren in the course of educational and extracurricular activities was based on the formation of their cognitive, emotional-volitional, activity and value components;

- "remote" training of primary school children in health saving was carried out using information technologies (video conferences in ZOOM);

- the process of forming the basic values for health education and health saving among students "took place" with the mandatory participation of parents and a team of scientific and pedagogical staff.

A study conducted at the initial stage on the awareness of children about their health and value attitudes towards it ("The methodology of the study of value orientations" by M. Rokich) showed disappointing results, both in the control and in the experimental groups (Figure 2 ) in the part of the content blocks - "Attitude to health", "Active life position", "The desire to be healthy" (Figure 3).

The analysis of the obtained results revealed a low level of formation of a value attitude to health in younger schoolchildren and the absence of statistically significant differences between the experimental and control groups of children.

Figure 2. Diagnostic data on the attitude to health in younger schoolchildren according to the content blocks of value hierarchies, $n=44$ (method of M. Rokich) 


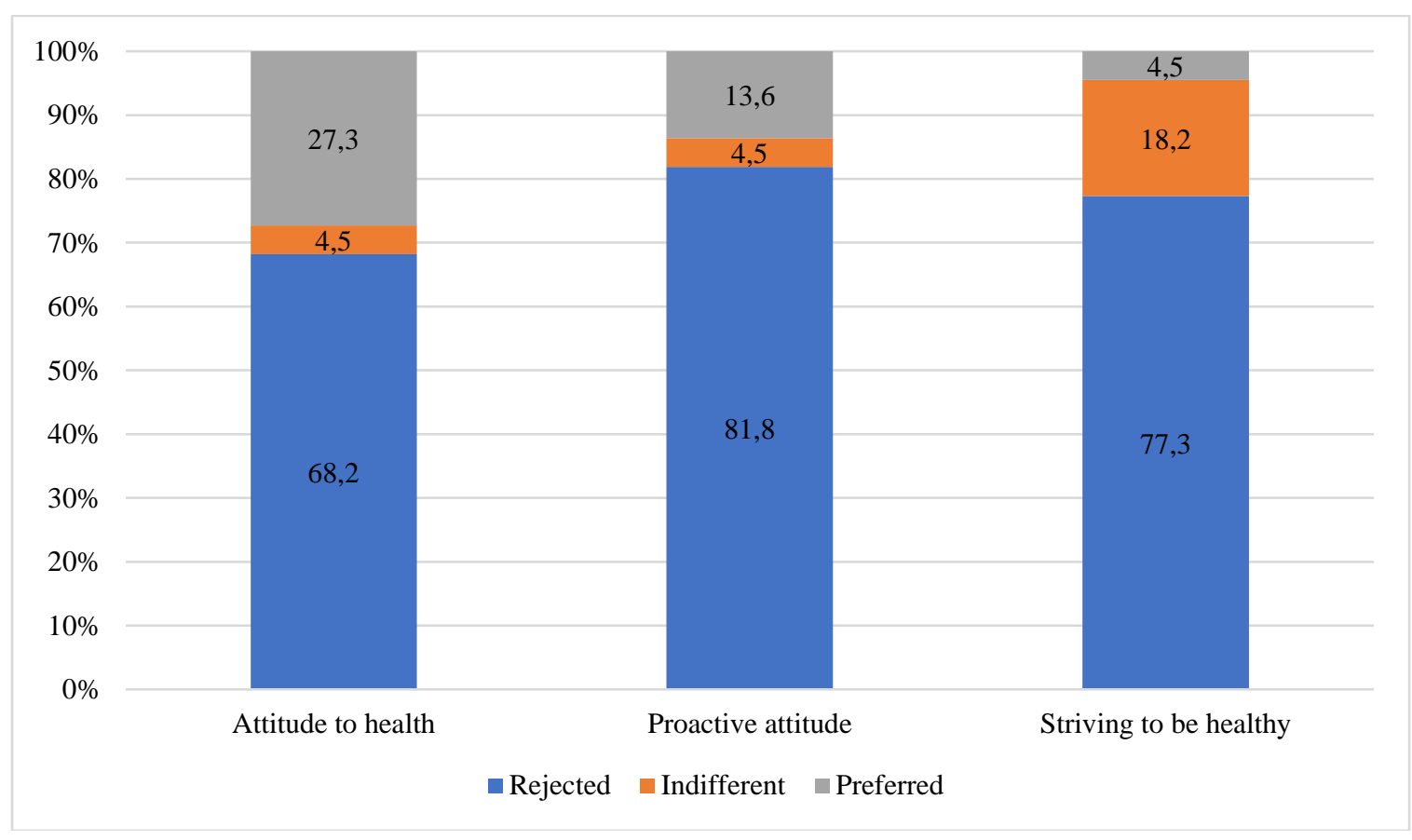

Figure 3. Diagnostic data for primary school children's attitudes to health ascertaining experiment, $\mathrm{n}=44$ (method of M. Rokich).

Attitude towards health according to observation data

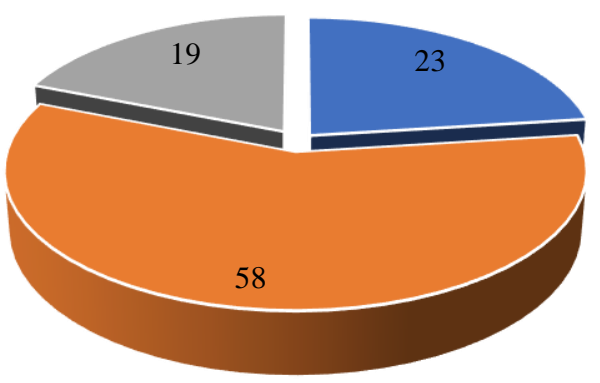

" Low activity " Average activity = High activity
Attitude to health according to the author's questionnaire "Attitude to health"

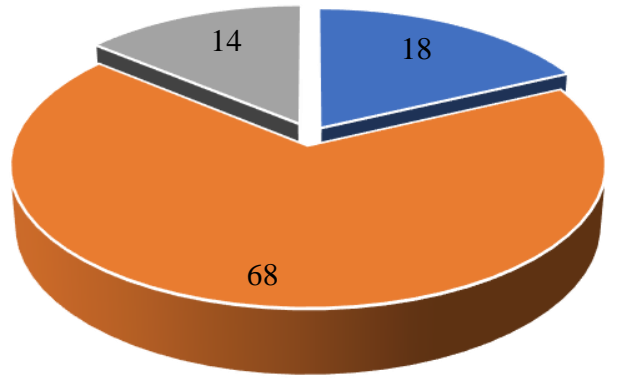

- Indifferent $=$ Does not think about it $=$ Appreciates health

In the course of the study, when working with younger schoolchildren, we used several certain types of activities aimed at increasing their motor and game activity and developing children's communication skills, cognitive and research activities (experimenting with objects of the surrounding world), as well as such activities as music perception (musical and rhythmic movements).

In the course of conducting extracurricular classes with younger schoolchildren in the motorgame form, we focused on the emotional component of the child, that is, we achieved optimal unity of affect and intelligence in extracurricular musical and rhythmic classes (Vygotskii, 1960). The presence of a pronounced situation and competition with the mandatory introduction of a system of incentives and penalties served as a criterion for evaluating the technologies of gaming activities for health saving in children. Another specific feature of game methods was the active use of motor 
cognitive processes by children (which, as is known, opens up great opportunities for the growth of connections between various functional systems) (Vygotskii, 1960).

The structure of experimentation itself was represented by a block of interrelated elements: the first block is the formulation of a problem (which required its resolution); the second block is goal-setting (how to do it to solve the problem); the third block is the hypothesis (search for all possible solutions); the fourth block is the verification of the hypothesis put forward; the fifth block is the analysis of the results obtained and, the sixth block is the formulation of conclusions.

Thus, the formation of the components of a value attitude to health and the conduct of a healthy lifestyle by younger schoolchildren required all participants in educational relations (children, parents, teachers, specialists) to carry out certain purposeful work to acquire the skills of health saving culture in lockdown conditions.

As is known, the core of the content of education (and in our case, education for healthsaving) (according to V.N. Belenov, R.A. Berezovskaya, V.S. Kuchmenko, E.N. Nazarova, G.S.Nikiforov, Yu.V. Novikov, etc.) is the presence of certain components in a person - cognitive, emotional-volitional, activity and value - (Figure 4) (Kalanchina, Apenysheva, 2019) (this scheme was adapted by us for the topic of our research).

Figure 4. Structural components of the attitude to health

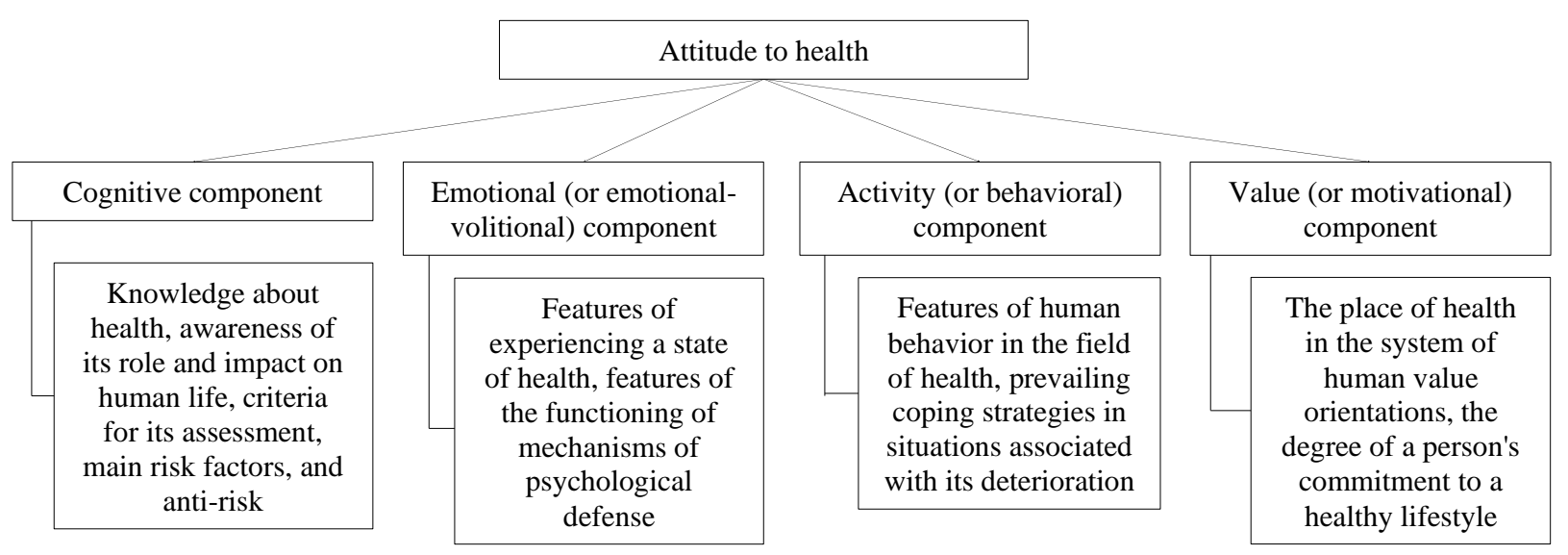

The formation of these components in students took place in educational and extracurricular activities in conditions of strict isolation. Therefore, in the process of educational and extracurricular work with children, we used mini-gymnastics; multi-media presentations; didactic games; activated and encouraged children's motor and play activities (video conferences in ZOOM); regularly held thematic conversations on the following topics: "Health as a value for a person", "Appearance as a reflection of our health", "How we move", "What we eat", "Bad habits", "Nerves, nerves ...". When conducting conversations with children, we adhered to a certain structure of it: we used a motivational component with the inclusion of mini-games, guessing riddles. Then the students were given a brief overview of obtaining new knowledge about maintaining their health and its importance; observations were discussed on the task proposed earlier to children; new knowledge on health saving was given; at the end of the lesson, the results were summed up and reflection was carried out. Parents of students took an active part (in lockdown conditions) in all these events, they accompanied the children and helped them during the distance learning period.

A theoretical analysis of modern research and the practice of teaching and educating younger schoolchildren on the problem of forming components of their value attitude to health and their healthy lifestyle revealed an extremely low level of their awareness. It became clear that the main role in this "familiarization" process on health education and health saving should belong to 
the school since it is in it that the student spends most of his/her time and it is the educational organization that has the widest range of various forms, methods, and means of educational work.

When developing the content of the program of the educational project, we used general pedagogical principles - scientificity and accessibility; value orientations, involving an appeal to the personal values of a person (child) as an important aspect of his/her life; consistency in the logic and nature of the presentation of information material; integration of health-saving knowledge, skills, and abilities in the life of children. In addition, we were also of the opinion that the cognitive and activity components of attitudes towards health directly depend on the emotional and value components. Only with orderly motivation, acceptance of the value of one's health in the internal psychological plane, a conscious need to make efforts to preserve it, it is possible to help children to learn the essence of the "health" and "healthy lifestyle" concepts, which will subsequently be realized by them in their purposeful activities. Therefore, we based the formation of a positive attitude to health among younger schoolchildren on the development of their value attitude to health and the desire to be healthy. Thus, all our efforts were aimed at the cognitive and behavioral spheres of children's activities and "fixed" their motivation and desire to be healthy; developed awareness in obtaining real results from physical activity by children made it possible for younger schoolchildren to receive psychological comfort and aesthetic bodily shape (Yakubenko, 2017).

Currently, the priority task of the National Security Strategy of the Russian Federation was and remains the strategy of "increasing the life expectancy of Russians; reducing the level of disability and mortality of the population, increasing its number" (Order of the Government of the Russian Federation No. 1375-r, 2018; Decree of the President of the Russian Federation No. 683, 2015). The current Federal Education Standards regulate that by the time of graduation, a child should already consciously follow the norms of a healthy lifestyle; take responsibility for his/her health, adhere to the rules of environmental safety. Therefore, this provision of the Federal Standard was and remains one of the priority pedagogical tasks, which, unfortunately, are still difficult to implement due to external and internal reasons (Lukashenko, Lukashenko, 2017; Shekhovtsova, Zinakov, 2018) (Figure 5).

Figure 5. Sections of the Plan of main activities for 2018-2020 in the framework of decades of childhood 


\section{Sections of the Plan of main activities for 2018-2020 in the framework of Decades of childhood}

\section{All Sections}

$\rightarrow$ Improving the well-being of families with children

$\rightarrow$ Modern infrastructure of childhood

$\rightarrow$ Ensuring the safety of children

$\rightarrow$ Healthy child

$\rightarrow$ Comprehensive education for children

$\rightarrow$ Cultural development of children

$\rightarrow$ Development of physical education and sports for children

$\rightarrow$ Safe children's rest

$\rightarrow$ Affordable children's tourism

$\rightarrow$ Safe information space for children

$\rightarrow$ The child and his/her right to a family

$\rightarrow$ Social protection of disabled children and children with disabilities and their integration into modern society

$\rightarrow$ Ensuring and protecting the rights and interests of children

$\rightarrow$ Quality children's goods and food

$\rightarrow$ Organizational activities

\section{Sections of the Plan of main activities for 2018-2020 in the framework of Decades of childhood}

Ensuring the safety of children

Healthy child

Development of physical education and sports for children

Safe children's rest

$\Rightarrow$ Affordable children's tourism

$\rightarrow$ Safe information space for children

$\rightarrow$ Quality children's goods and food

Most modern Russian schools currently use traditional health-saving measures. These are quizzes, leisure activities, the organization of targeted campaigns (for example, "It's fashionable to be healthy!" action), competitive sports and entertainment programs (for example, "The young generation chooses health"), game programs (for example, "In the country of health!"), etc. These events are organized for the most part, as a rule, on a one-time basis and are (for the most part) educational; they do not form components of a value attitude to health in children. It is noteworthy that until now, most children have little idea of how to preserve and strengthen their health; they are poorly oriented in matters of a healthy lifestyle. Therefore, one of the tasks of our research was to determine the indicators of the effectiveness of the use of the "Health of the child's saving space in an innovative educational environment" educational model using an educational project. The results obtained in the course of the study indicated that primary schoolchildren are good at assimilating facts that change their system of ideas about health and health savings.

The teacher, preparing for academic and extracurricular classes on health saving, worked in advance with scientific and educational material; prepared the educational environment and all the necessary material for it in advance. All the work carried out by scientific and pedagogical workers was carried out in a "remote" mode and was of a regularly planned nature. In the course of the study, we used thematic presentations, mini-gymnastics, conversations about health and a healthy lifestyle were mandatory in the lessons; students carried out systematic self-monitoring of their health indicators. All these studies were conducted with the direct participation of parents, who daily monitored the educational activities of children in full-time and distance learning.

During the implementation of the educational and leisure process with younger schoolchildren, we used a complex thematic model of conducting classes, which was very interesting to students, and health-saving education became meaningful and motivated for them. With such an organization of the educational process, it became possible to ensure the unity of 
educational, developmental, and educational tasks under the program of the health-saving upbringing of children.

The construction of the educational process considering educational areas, the application of the "Health of the child's saving space in an innovative educational environment" model contributed to the formation and development of a certain culture of health and health saving among younger schoolchildren. As a result, children in their development of knowledge, skills, and abilities have reached an independent level of knowledge of the necessary aspects of maintaining their health and strengthening it.

In the course of working with younger schoolchildren and their parents, we developed and implemented an educational project - " Formation of components of a value attitude to health among younger schoolchildren using information technologies in an innovative educational environment "(Figure 6).

Figure 6. The "Formation of components of a value attitude to health in younger schoolchildren using information technologies in an innovative educational environment" educational project

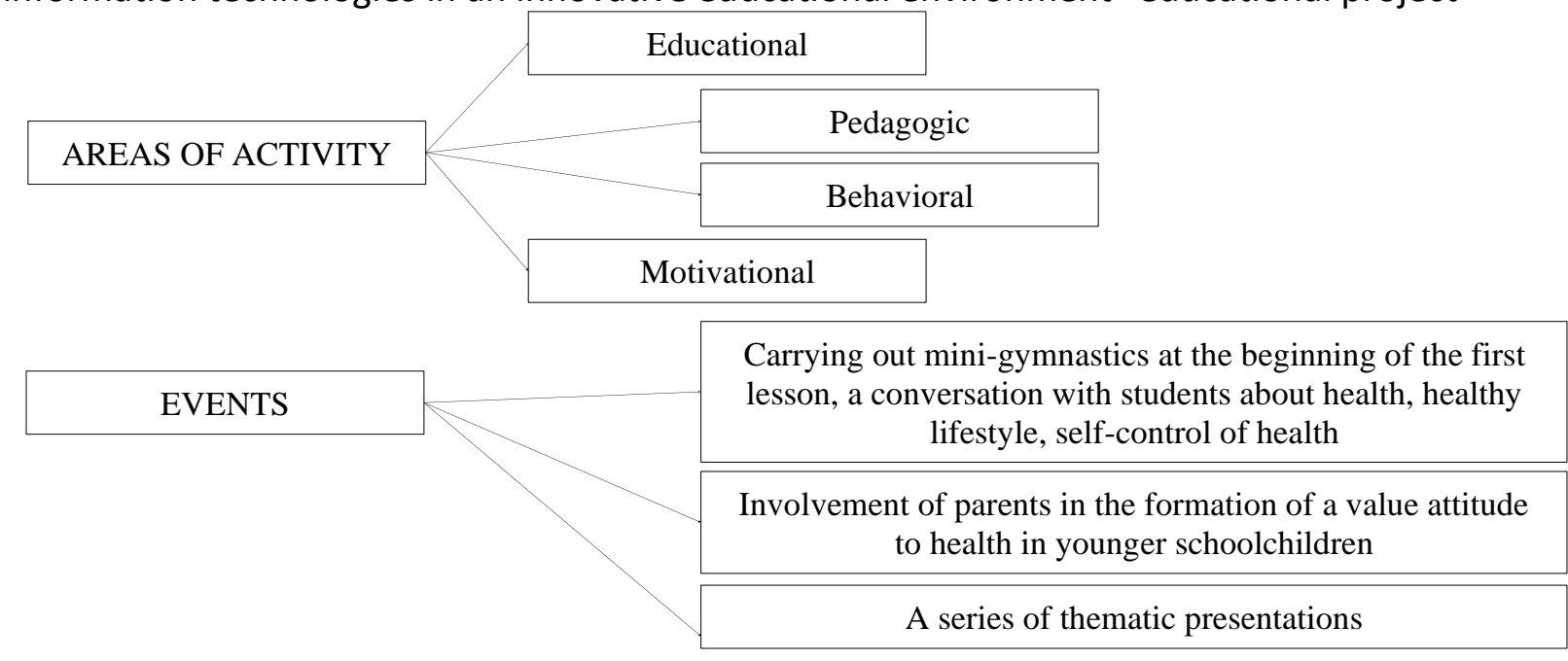

This project spelled out the pedagogical conditions, areas of activity, and all the necessary measures for working with children and their parents:

$>$ education of a value attitude to health in the course of educational and leisure activities of younger schoolchildren based on the formation of its components: cognitive, emotional (or emotional-volitional), activity (or behavioral), and value (or motivational).

$>$ the use of information technologies for the formation of a value attitude to health among younger schoolchildren.

$>$ involvement of parents in the process of forming a valuable attitude to health among younger schoolchildren.

Carrying out the pedagogical process in the key of health saving, the teacher himself/herself had a certain level of health saving culture, was prepared, and was a creatively active person. When working on a training project on health saving, we used an integrated model of the educational process, which was developed by Professor N. V. Miklyaeva (2015). The use of this model allowed considering the regime moments of the educational institution concerning the organization of teaching the subject-spatial environment; it helped in the implementation of independent activities of children and their joint activities with adults. In addition, the entire organization of cognitive training of younger schoolchildren on health saving was built based on practical knowledge of the world, which was the educational project. It was the project activity in action that allowed developing the ability of children to cooperate; developing their cognitive aspects; acquiring 
research skills; learning children to think critically, making decisions on their health savings, navigating in the information health-saving space. We used a combination of several types of projects (play, creative, research) in the practice of health education, in which we applied various forms of organizing work with children (experimentation, modeling, research activities). Also, a "Health" corner was organized for children in the classroom, which had all the necessary material for conducting health-saving classes during school hours (video conferences in ZOOM).

When forming a value-based attitude to health among younger schoolchildren, the teacher used didactic games with modeling of problem situations, as well as all aspects of children's motor and play activity. All this helped the children to form certain figurative ideas about the processes of health saving and "formed" the basis of their independent judgments, concepts, feelings, emotions in the future. The students were able to comprehend the information received and form their attitude to health.

Thus, a certain organization of the pedagogical process for the formation of a value-based attitude to health among younger school children in an innovative educational environment (lockdown) contributed to the development of certain moral qualities in them - awareness, responsibility, rationality. Children began to get a feel for the culture of health, to take into account the role and importance of the external environment, its influence on them. In parallel with the implementation of educational work with children, the teacher also worked with the parents of children, since it has long been known that the effectiveness of the formation of the culture of a younger student depends on adults' awareness of the meaning of educational activities.

At present, in our opinion, insufficient attention is paid in research to the specifics of the pedagogical impact and the work of specialists of an educational organization with the family (the child's parents, custodians, etc.). The main goal is to provide assistance and teach the basics of forming a culture of health savings for children with the mandatory participation of family members. In this regard, we also worked with the student's family in parallel during the period of strict isolation. The active participation of the children's parents was also since it was interesting for the parents themselves to clarify their knowledge, draw analogies, observe and fix certain patterns together with the children. In the conditions of using an innovative educational environment, parents were consulted by sending materials via the Internet in a convenient way for them. Counseling was conducted on the issues of raising children and maintaining a healthy lifestyle; joint viewing of educational and cognitive material (using information technologies) was carried out; monitoring of children's physical activity was carried out; conversations with children and parents about their healthy lifestyle were conducted; self-control training was provided for their health; conditions were created for joint recreational and play activities of children and parents to preserve and improve their health; consultations were also held for parents on the topic "The role of the family in the formation of a child's value attitude to health" or "The importance of their example in the formation of a child's value attitude to health". The consultation was carried out by sending out the consultation material. The educational process for parents in an innovative educational environment was based on the question-answer type using video conferences in ZOOM. Multimedia thematic presentations were especially popular, which parents watched together with their children (they guessed riddles, played games, analyzed the viewed material). The general assessment of parents: "Useful information, not tedious to view".

Based on the results of the study (the results are reflected in the next section of the article), we designed the "Health - saving space of a child in an innovative educational environment" model, which was implemented in the practice of educational and extracurricular activities using an educational project. The tasks were solved in the course of the study.

The control stage of the study 
After the work with younger schoolchildren with the participation of a team of specialists, we conducted a repeated diagnosis according to the" Methodology for the study of value orientations " by M. Rokich "Dynamics of attitude to health in younger schoolchildren according to the content blocks of value hierarchies" ("Attitude to health", "Active life position" and "Desire to be healthy"), which showed a significant increase in the number of children participating in the educational project and revealed their priorities (Figure 7).

Figure 7. The dynamics of the attitude to health in younger schoolchildren according to the content blocks of the hierarchy of values (M. Rokich).

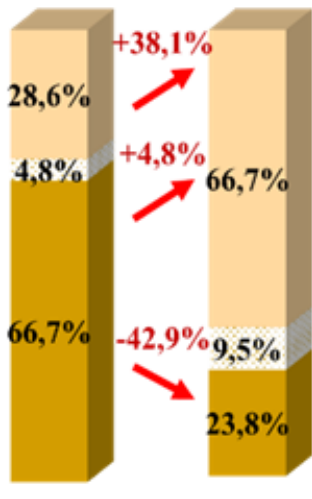

Attitude to health

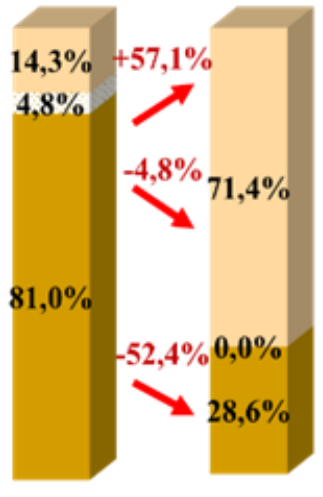

Proactive attitude

Experimental group of children, $n=21$
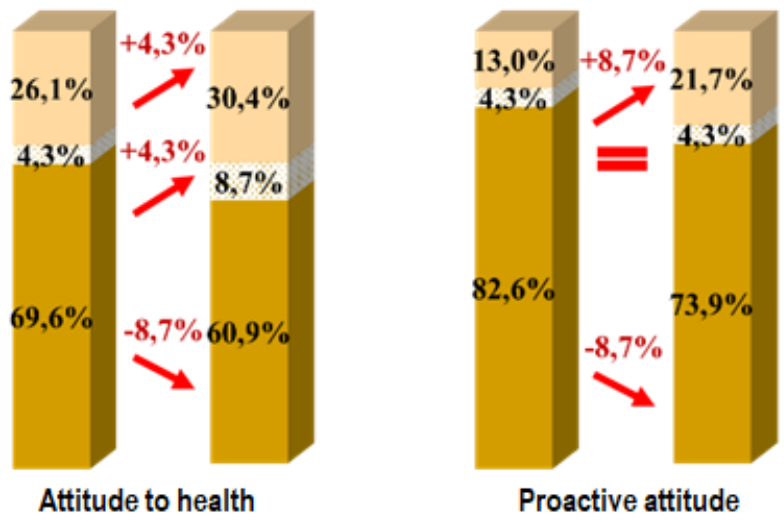

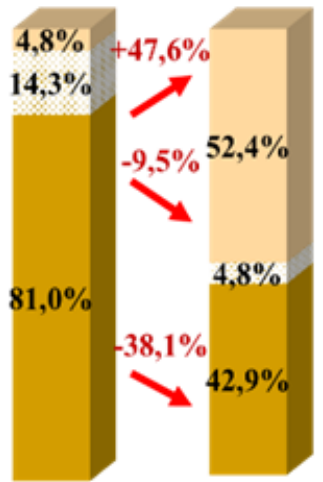

Striving to be healthy

nejected

Indifferent

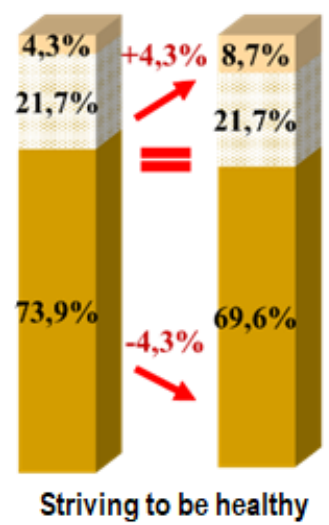

Preferred

Control group of children, $n=23$

The study showed that a significant number of children in the experimental group had increased activity; children began to value their health. These changes were insignificant in the control group. We observed a similar picture in the block of the M. Rokich methodology "Dynamics of attitude to health in younger schoolchildren" according to the observation data.

The conducted qualitative and quantitative analysis showed the effectiveness of purposeful psychological and pedagogical work on the formation of components of a value attitude to health in younger schoolchildren in lockdown conditions and confirmed that for its formation it is necessary to use the "Health saving space of a child in an innovative educational environment" model.

\section{CONCLUSION}

A study on the formation of a value attitude to health among younger school children in an innovative educational environment showed a high level of interest among children when they study the content bases for the organization of health education and health savings in the space of educational and extracurricular activities. The experimental use of the "Health-saving space of a child in an innovative educational environment" model and the evaluation of the effectiveness of 
its application using an educational project in lockdown conditions confirmed the need for its "implementation" in the educational process of primary school.

The purposeful work of the teacher with younger schoolchildren in the "remote" mode (video conferences in ZOOM) on the issues of educational and health-saving activities (with the participation of a team of specialists and parents) contributed to:

- early formation of a health culture among students;

- development of children's skills and abilities to lead a healthy lifestyle, strengthening the desire of younger schoolchildren to continue studying the issues of health savings in the future.

Thus, the hypothesis put forward by us about the need for early formation of a value attitude to health in children has been confirmed.

Designing a meaningful basis for the health and safety of students in the context of an innovative educational process helps to realize the deep potential of each child and form the "layer" of healthy people that Russia needs so much.

The design and content bases outlined above, the health of education and the health of students' savings, give a new meaning to the educational process of modern schools and are a unique means of preserving and strengthening the health of younger schoolchildren.

Thus, the challenges of the modern and rapidly changing world "push" pedagogical science and its new directions, for example, health-saving pedagogy, to develop.

Authors' Contributions: Victor Konstantinovich Vittenbek: conception and design, acquisition of data, analysis and interpretation of data, drafting the article, critical review of important intellectual content. Maryam Rashidovna Koreneva: conception and design, acquisition of data, analysis and interpretation of data, drafting the article, critical review of important intellectual content. Konstantin Pavlovich Yadrov: conception and design, acquisition of data, analysis and interpretation of data, drafting the article, critical review of important intellectual content. Galina Pavlovna Ivanova: conception and design, acquisition of data, analysis and interpretation of data, drafting the article, critical review of important intellectual content. Anna Sergeevna Moskvina: conception and design, acquisition of data, analysis and interpretation of data, drafting the article, critical review of important intellectual content. All authors have read and approved the final version of the manuscript.

Ethics Approval: Not applicable.

Acknowledgments: Not applicable.

\section{REFERENCES}

Alonkina, N.I. (2014). "School of Health" program. Retrieved from: https://infourok.ru/kompleksnaya_programma_zdorovye_v_obscheobrazovatelnoy_shkole-176971.htm

Ankov, V. (2017). Rospotrebnadzor named the number of absolutely healthy children in Russia. RIA News. Retrieved from: https://ria.ru/society/20170913/1504653450.html

Bryantseva, M.V., Vittenbek, V.K., Yadrov, K.P., Pastukhova, D.A., Ivanova, G.P. (2019). Study on the motivation and needs of students for e-learning at a university. Amazonia Investiga, 8(24), 431-440.

Decree of the President of the Russian Federation No. 683. (December 31, 2015). "On the National Security Strategy of the Russian Federation". Retrieved from: https://base.garant.ru/71296054/

Decree of the President of the Russian Federation No. 761. (June 1, 2012). "On the National Strategy of Actions in the interests of Children for 2012-2017". Retrieved from: https://base.garant.ru/70183566/

Dmitrieva, L. (2016). The program for the formation of healthy lifestyle skills for children 7-10 years old "Health Secrets". Retrieved from: https://www.maam.ru/detskijsad/programa-po-formirovaniyu-navykov-zdorovogo-obrazazhizni-dlja-detei-7-10-let-sekrety-zdorovja.html

Dolgopolov, S.R. (2012). Schoolchildren's Health Program. Retrieved from: https://nsportal.ru/nachalnayashkola/vospitatelnaya-rabota/2012/12/04/programma-zdorove-shkolnika 
Kalanchina, I.N., Apenysheva, L.G. (2019). Pravoslavnoe napravlenie v sovremennykh issledovaniyakh v oblasti ozdorovitelnykh praktik i metodov [Orthodox trend in modern research in the field of health-improving practices and methods]. Zdorove cheloveka, teoriya i metodika fizicheskoi kultury i sporta, 5(16), 48-54.

Kamakina, O.Yu. (2017). Osobennosti otnosheniya k zdorovyu mladshikh shkolnikov raznogo pola [Features of attitudes towards the health of younger schoolchildren of different sexes]. Obshchestvo: sotsiologiya, psikhologiya, pedagogika, 2, 41-43.

Kazakovtsev, T.S. (2018). "Health from childhood" partial program. Retrieved from: https://nsportal.ru/detskiysad/zdorovyy-obraz-zhizni/2018/03/26/programmy-po-fiz-razvitiyu

Kaznacheev, V.P. (2012). Zdorove natsii, kultura, futurologiya 21 veka. Sb. statei i dokl. V.P. Kaznacheeva (2007-2012.) [Health of the nation, culture, futurology of the 21st century. Collected papers. V.P. Kaznacheev (2007-2012)]. Novosibirsk: ZSO MSA.

Lukashenko, N.P., Lukashenko, D.A. (2017). Formirovanie predstavlenii o zdorovom obraze zhizni u doshkolnikov [Formation of ideas about a healthy lifestyle among preschoolers]. Psikhologiya, sotsiologiya i pedagogika, 2, 8-10.

Miklyaeva, N.V. (2015). Ekspress - konstruktor obrazovatelnoi programmy: metodicheskoe posobie [Express constructor of the educational program: methodological guide]. Moscow: Sfera.

Order of the Government of the Russian Federation No. 1375-r. (July 6, 2018). "On the approval of the plan of main activities for 2018-2020 within the framework of the Decade of Childhood". Retrieved from: http://government.ru/docs/33158/

Pleshchev, A.M. (2018). Glavnye sostavlyayushchie zdorovogo obraza zhizni [The main components of a healthy lifestyle]. Vestnik ShGPU, 3(39), 39-43.

Shcherbakov, V.P. (2018). Partial program "Physical education from 3 to 17 years" /- URL: https://nsportal.ru/detskiysad/zdorovyy-obraz-zhizni/2018/03/26/programmy-po-fiz-razvitiyu (reference date: January 4, 2020).

Shekhovtsova, Yu.A., Zinakov, E.A. (2018). Strategiya ekonomicheskoi bezopasnosti Rossiiskoi Federatsii na period do 2030 goda, ee preimushchestva i puti sovershenstvovaniya [The strategy of economic security of the Russian Federation for the period up to 2030, its advantages and ways of improvement]. Ekonomika, upravlenie, finansy: materialy VIII Mezhdunar. nauch. konf. [Economics, management, finance: materials of the 8th. Intern. scientific. conf.]. Krasnodar: Novatsiya, pp. 34-37.

Tsyrenova, L.Zh. (2015). Zdorove - sberegayushchie tekhnologii v nachalnoi shkole [Health - saving technologies in primary school]. Pedagogika: traditsii i innovatsii: materialy VI Mezhdunar. nauch. konf. [Pedagogy: traditions and innovations: materials of the 6th. Intern. scientific. conf.]. Chelyabinsk: Dva komsomoltsa, pp. 166-169.

Vittenbek, V.K., Maksimenko, Zh.A. (2019). Vzaimosvyaz uchebnoi motivatsii i adaptatsii obuchayushchikhsya nachalnykh klassov $v$ sovremennoi shkole [The relationship between educational motivation and adaptation of primary school students in a modern school]. Novoe v psikhologo-pedagogicheskikh issledovaniyakh: Teoreticheskie i prakticheskie problemy psikhologii i pedagogiki. Nauchno-prakticheskii zhurnal, 3(55), 155-163.

Voitenkova, N.M., Martynov, O.P. (2012). "Formation of a healthy lifestyle among children from orphanages aged 7 to 14" program. Retrieved from:

https://edetskiydom.ucoz.ru/publ/programmy/formirovanie_zdorovogo_obraza_zhizni_u_vospitannikov_detskikh_do mov_v_vozraste_ot_7_do_14_let/2-1-0-5

Vygotskii, L.S. (1960). Razvitie vysshikh psikhicheskikh funktsii [Development of higher mental functions]. Moscow: Publishing House APN RSFSR.

Yadrov, K.P. (2016a). Teoretiko-metodologicheskie podkhody $\mathrm{k}$ issledovaniyu roli subekta $v$ innovatsionnykh protsessakh [Theoretical and methodological approaches to the study of the role of the subject in innovative processes]. Innovatsionnaya deyatelnost v obrazovanii : Materialy 10oi Mezhdunarodnoi nauchno-prakticheskoi konferentsii [Innovative activity in education: Materials of the 10th International scientific and practical conference], Moscow-Pushkino, April 19, 2016. Moscow - Pushkino: Publishing House "Kantsler", pp. 459-466.

Yadrov, K.P. (2016b). Rol samoanaliza subekta innovatsionnoi deyatelnosti [The role of self-analysis of the subject of innovation]. Sotsiokulturnaya determinatsiya subektov obrazovatelnogo protsessa: sbornik materialov mezhdunarodnoi konferentsii 11 Levitovskie chteniya v MGOU [Sociocultural determination of the subjects of the educational process: collection of materials of the international conference, 11th Levitov readings at MGOU], Moscow, April 20-21, 2016. Moscow: Moskovskii gosudarstvennyi oblastnoi universitet, pp. 321-324. 
Yakubenko, O.V. (2017). Vospitanie otvetstvennogo otnosheniya k zdorovyu obuchayushchikhsya [Fostering a responsible attitude to the health of students]. Elektronnyi nauchno-metodicheskii zhurnal Omskogo GAU, 1(8), 58Retrieved from: https://cyberleninka.ru/article/n/vospitanie-otvetstvennogo-otnosheniya-k-zdorovyuobuchayuschihsya

Zimina, I.S., Mukhina, S.A. (2016). Sushchnost, soderzhanie i struktura zdorove sberegayushchei obrazovatelnoi sredy vuza [The essence, content and structure of the health-saving educational environment of the university]. Vestnik Mariiskogo gosudarstvennogo universiteta, 4(24), 16-21.

Received: 31 July 2021 | Accepted: 12 September 2021 | Published: 18 November 2021

This is an Open Access article distributed under the terms of the Creative Commons Attribution License, which permits unrestricted use, distribution, and reproduction in any medium, provided the original work is properly cited. 